\title{
Pengembangan Performance Assessment untuk Mengukur dan Memetakan Practical Skills IPA Siswa pada Guided-PjBL di SMP
}

\author{
Siska Pratama ${ }^{1}$, Dadan Rosana ${ }^{2}$ \\ 12 Program Studi Pendidikan Sains, Program Pascasarjana, Universitas Negeri Yogyakarta \\ Jalan Colombo No. 1, Karangmalang, Yogyakarta 55281, Indonesia \\ * Korespondensi Penulis. Email: siskapratama14@gmail.com
}

\begin{abstract}
Abstrak
Penelitian ini bertujuan untuk: (1) mengetahui karakteristik performance assessment yang valid dan reliabel untuk mengukur practical skills IPA pada guided-PjBL, (2) mendeskripsikan practical skills IPA yang muncul pada guided-PjBL, dan (3) mengetahui peta practical skills IPA siswa SMP menggunakan performance assessment. Penelitian ini merupakan Research \& Development dengan menggunakan model 4-D Thiagarajan, et al. (1974). Subjek uji coba adalah siswa kelas VII di SMPN 1 Wonosari, SMPN 4 Playen, dan SMPN 5 Ngawen.Teknik pengambilan data meliputi wawancara, angket, dan nontes. Instrumen pengambilan data meliputi pedoman wawancara, lembar angket, dan lembar observasi. Hasil penelitian ini yaitu performance assessment dalam bentuk lembar observasi dinyatakan valid dan reliabel. Practical skills IPAyang muncul pada guided-PjBL meliputi: merancang proyek; menggunakan termometer dan indikator universal; membaca hasil pengukuran suhu dan $\mathrm{pH}$; membuat tabel; menentukan variabel bebas dan terikat; membuat grafik; mengetahui hubungan antarvariabel; dan membuat kesimpulan. Siswa pada sekolah kategori tinggi memiliki tingkat kemampuan practical skills paling tinggi bila dibandingkan dengan siswa pada sekolah kategori sedang dan rendah. Siswa pada sekolah kategori sedang memiliki tingkat kemampuan practical skills paling rendah.
\end{abstract}

Kata Kunci: performance assessment, lembar observasi, guided-PjBL, practical skills IPA

\section{Developing Performance Assessment to Map Science Practical Skills on Guided-PjBL}

\begin{abstract}
This study aims to: (1)find out the characteristic of performance assessment that is valid and reliable to measure science practical skills on guided-PjBL, (2) describe science practical skills that appear on guided-PjBL, and (3) find out the map student's science practical skills in junior high school to use performance assessment on guided-PjBL. This was a research and development study employing the development model by Thiagarajan et al. (1974).The tryout subjects were junior high school student in SMPN 1 Wonosari, SMPN 4 Playen, and SMPN 5 Ngawen. The data were collected through interviews, questionnaires, and nontests. The data collecting instruments included an interview guided, validation questionnaire sheets, and observation sheets. The result of the study was the product of performance assessment in observation sheet form was valid and reliable. Science practical skills that appear on guided-PjBL. included: designing project; using thermometre and universal indicator; reading temperature and pH measurement; creating table; defining independentdependent variable; creating graph; find out relation between variable; and drawing conclusion. The students in the school with the high category have the highest science practical skills of the three schools. The students in the school with the low category have higher science practical skills than students in high grade school.
\end{abstract}

Keywords: performance assessment, observation sheet, guided-PjBL, science practical skills

How to Cite: Pratama, S., \& Rosana, D. (2016). Pengembangan performance assessment untuk mengukur dan memetakan practical skills IPA siswa pada guided-PjBL di SMP. Jurnal Inovasi Pendidikan IPA, 2(1), 100-110. doi:http://dx.doi.org/10.21831/jipi.v2i1.8372

Permalink/DOI: http://dx.doi.org/10.21831/jipi.v2i1.8372 


\title{
Jurnal Inovasi Pendidikan IPA, 2 (1), 2016 - 101
}

\author{
Siska Pratama, Dadan Rosana
}

\section{PENDAHULUAN}

Undang-undang Nomor 20 Tahun 2003 tentang Sistem Guruan Nasional pada pasal 3 berisi tentang fungsi dan tujuan guruan nasional. Fungsi dan tujuan tersebut menjadi tolak ukur utama untuk merumuskan Standar Nasional Pendidikan (SNP). Standar Kompetensi Lulusan (SKL) dibutuhkan untuk mencapai tujuan guruan nasional. Pasal 1 ayat 4 Peraturan Pemerintah RI Nomor 19 Tahun 2005 menyebutkan SKL merupakan kualifikasi kemampuan lulusan yang mencakup sikap, pengetahuan, dan keterampilan. SKL digunakan sebagai acuan utama dalam pengembangan tujuh SNP, salah satunya adalah Standar Penilaian.

Standar penilaian merupakan salah satu SNP yang mengalami revisi dengan adanya penyempurnaan Kurikulum Tingkat Satuan Pendidikan 2006 (KTSP 2006) menjadi Kurikulum 2013. Hal tersebut dilakukan karena penilaian yang selama ini dilakukan hanya mengukur pada kompetensi pengetahuan saja.

Pada kenyataannya, penilaian kompetensi keterampilan yang selama ini dilakukan di sekolah justru mengarah kepada penilaian produk. Hal tersebut tidak sesuai dengan esensi yang ada pada penilaian kompetensi keterampilan. Idealnya penilaian kompetensi keterampilan dilakukan melalui penilaian kinerja (performance assessment), yaitu penilaian yang menuntut siswa mendemonstrasikan suatu kompetensi tertentu dengan menggunakan tes praktik, proyek, dan penilaian portofolio.

Performance assessment merupakan penilaian yang dilakukan dengan mengobservasi kegiatan siswa dalam melakukan suatu kegiatan. Menurut Zainul (2001, p.9), wujud performance assessment yang utama adalah task dan rubric. Tugas dari performance assessment dapat diwujudkan dalam bentuk group performance assessment, individual performance assessment, observasi, portofolio, dan project, exhibition, or demonstrasion.

Berdasarkan hasil wawancara kepada guru IPA di beberapa SMP yang ada di Kabupaten Gunungkidul, ditemui kendala yang berhubungan dengan performance assessment, diantaranya guru masih mengalami kebingungan tentang tata cara dalam membuat perangkat performance assessment, keterbatasan waktu dan jumlah siswa dalam satu kelas yang cukup banyak, serta beban mengajar guru dalam satu semester cukup tinggi yaitu 24 jam pembelajaran guna memenuhi tuntutan sertifikasi. Selain hal tersebut, siswa masih jarang melakukan performance baik dalam bentuk tes praktik, projek, dan portofolio sehingga practical skills siswa tidak dapat terukur dengan baik.

Hampton (2002, p.83) menyatakan bahwa pembelajaran practical skills paling sering menggunakan aktivitas laboraturium dan workshop, khususnya berkaitan dengan alat dan bahan dengan ukuran kelas yang kecil dan membutuhkan waktu yang lama. Central Board of Secondary Education (2009, pp.13-14) menyebutkan bahwa perkembangan practical skills meliputi procedural and manipulative skills, observational skills, drawing skills, dan reporting and interpretative skills.

Selain terkendala pada proses penilaian keterampilan, berdasarkan hasil wawancara dengan beberapa guru IPA di SMPN yang ada di Kabupaten Gunungkidul, ternyata guru mengalami kendala dalam menggunakan model, pendekatan atau metode pembelajaran. Sampai saat ini, sebagian guru belum mampu menerapkan pembelajaran berbasis Discovert Learning, Inquiry Learning, Problem Based Learning (PBL), dan Project Based Learning (PjBL) seperti yang diamanatkan dalam Kurikulum 2013. Untuk menyampaikan materi IPA, guru cenderung menggunakan cara lama, yaitu dengan metode ceramah dan demonstrasi. Padahal setiap materi IPA pada kompetensi pengetahuan dan keterampilan dapat menggunakan pembelajaran berbasis Discovert Learning, Inquiry Learning, PBL, dan PjBL yang disesuaikan dengan materi yang akan disampaikan.

Hosnan (2014, p.319) mengemukakan bahwa PBL dan PjBL sama-sama menekankan lingkungan belajar siswa aktif, kerja kelompok, dan authentic assessment. Namun perbedaannya terletak pada objeknya. PBL, pembelajaran lebih didorong dalam kegiatan yang memerlukan perumusan masalah, pengumpulan data, dan analisis data, sedangkan $\mathrm{PjBL}$ lebih didorong dalam kegiatan desain, merumuskan tindakan, merancang tindakan, mengkalkulasi kemungkinan tiap tindakan, melaksanakan tindakan, dan mengevaluasi hasil.

Berdasarkan permasalahan yang telah diuraikan, maka diperlukan penelitian pengembangan performance assessment untuk mengukur practical skills IPA siswa pada guidedPjBL di SMP. Performance assessment yang dikembangkan dalam bentuk lembar observasi.

Wisconsin Education Association Council (1996), van Helvoort (2010), dan Wren (2009) 
mengemukakan bahwa penilaian kinerja merupakan salah satu penilaian yang

mengharuskan siswa untuk mendemonstrasikan keterampilan khusus dan kompetensi yang telah mereka kuasai dengan melakukan atau menghasilkan sesuatu. Miller, Linn, \& Groundlund (2009, pp.260,267) mengemukakan bahwa penilaian berbasis kinerja menekankan pada mengerjakan, tidak hanya mengetahui proses sebagaimana produk.

Paige (2005, p.102) mengemukakan bahwa penilaian kinerja merupakan proses yang terdiri atas mendefinisikan, memilih, mendesain, mengumpulkan, menganalisis, menginterpretasi, dan menggunakan informasi.

Zitzewitz (2004, p.6) menyatakan bahwa penilaian kinerja tidak dapat dievaluasi menggunakan tes tertulis. Performance assessment terdiri atas dua komponen utama, yaitu task dan rubric. Performance task melibatkan pemahaman konsep ilmiah dan prodesur. Rubric merupakan alat evaluasi yang digunakan untuk menilai kinerja siswa (Craw, 2009, p.109) dan juga menilai produk siswa (Wolf \& Stevens (2007, p.3).

Wisconsin Education Association Council (1996, pp.4-6), van Helvoort (2010, p.27), Wolf \& Stevens (2007, pp.5-7), Kunandar (2014: pp.267-268) menyatakan bahwa pada dasarnya pengembangan performance assessment terdiri atas tiga komponen penting, yaitu (a) mendefinisikan tujuan, (b) memilih kegiatan, dan (c) mengembangkan kriteria penskoran.

Berdasarkan pemaparan tentang performance assessment dapat disimpulkan bahwa performance assessment merupakan penilaian yang mengharuskan siswa untuk melakukan suatu task yang nantinya task tersebut akan dinilai oleh guru menggunakan rubric. Pada penelitian, task yang dilakukan siswa dalam bentuk proyek dan dinilai dengan lembar observasi.

Performance assessment yang dikembangkan diterapkan pada guided-PjBL. PjBL merupakan model pembelajaran yang menggunakan pendekatan pembelajaran siswa terhadap masalah autentik (konstruktivisme) (Mihardi, 2013, p.190 dan Bender, 2012, p.7). Kegiatan PjBL berpusat pada siswa (Bagheriet al., 2013, p.18). Siswa diminta menerapkan pengetahuan dalam memecahkan masalah kemampuan membuat keputusan, pencapaian produk akhir yang relevan dengan pertanyaan atau masalah (Pickenset al., 2012, p.3).

Langkah-langkah pembelajaran dalam Project Based Learning sebagaimana yang dikembangkan oleh The George Lucas Educational Foundation (2005) terdiri atas: (a) start with essential question; (b) design a plan for the project; (c) create a schedule; (d) monitor the students and the progress of the project; (e) assess the outcome; dan (f) evaluate the experience.

McGrath (2002, pp.42-44) mengemukakan langkah-langkah dalam menyusun proyek yaitu:(a) choosing topic,(b) discussing and refining the topic, (c) planning the project, (d) researching the topic, (e) leading your students, (f) evaluating and critiquing the project, dan (g) presenting the works created.

Keser \& Karahoca (2010, p.5756) menggambarkan tahapan PjBL meliputi: (a) defining goals, (b) determining the problem, (c) defining preferences of result report, (d) defining evaluation metric and qualification, (e) creating and management team, (f) defining sub problems and data collecting process, (g) defining working scedule, defining control points, (h) collecting data, organizing the data and reporting, dan (i) presenting project report.

Langkah pembelajaran dalam Project based Learning menurut Patton (2012, pp.3469) meliputi (a) get an idea, (b) design the project, (c) tune the project, (d) do the project, dan (e) exhibit the project.

Pada model project based learning, siswa diberikan kebebasan dalam memilih proyek, sementara guru tidak hanya sebagai sumber belajar, tetapi juga bertindak sebagai fasilitator dan pembimbing (Guo, 2012, p.43). Siswa Indonesia sekarang yang masih bergantung pada guru, pelaksanaan model project based learning mungkin tidak akan berjalan sesuai harapan. Di samping itu, muatan konten kurikulum di Indonesia masih sangat banyak, yang mengakibatkan waktu yang diberikan untuk satu pokok bahasan menjadi sangat terbatas.

Proyek yang dilakukan dapat ditentukan oleh guru. Guru dan siswa berkolaborasi sebagai team melalui project based learning. Model tersebut dikenal dengan istilah student-guided service learning project yang melibatkan siswa dalam proses desain teknologi yang membangun dan meningkatkan konten pengetahuan, kemampuan pemecahan masalah, sistem berpikir, dan keterampilan komunikasi (Bakeret al., 2011, p.1). Project based learning yang dibimbing selanjutnya akan dikenal dengan Guided-Project Based Learning.

Berdasarkan beberapa definisi yang telah dipaparkan sebelumnya, dapat disimpulkan 
bahwa Project Based Learning merupakan kegiatan siswa dalam merancang, merencanakan dan melaksanakan sebuah proyek yang nantinya akan menghasilkan sesuatu yang dapat dipamerkan, dipublikasikan, atau dipresentasikan. Dikarenakan siswa masih tergantung pada guru, maka Project Based Learning dimodifikasi menjadi Guided-Project Based Learning.

Watts (2013, p.4) mengemukakan beberapa tujuan pada kerja praktik secara umum meliputi: (a) mengembangkan keterampilan memanipulasi,(b) mengetahui teknik standar,(c) memahami pengolahan data, (d) mengevaluasi, (e) merencanakan, (f) mengembangkan keterampilan menganalisis, dan (g) memahami bagaimana kerja sains. Selain itu Lock (1989, p.221) mengemukakan bahwa komponen practical skills meliputi observing, manipulating, planning, interpreting, reporting, dan reliance. Sejalan dengan pemikiran Lock (1989, p.221), Wood, Ferguson, \& Carolyn (1975, p.605) mengungkapkan bahwa practical skills meliputi manipullative skills, observational skills, interpretation skills, and creative skills. Woodley (2009: p.50) mengemukakan bahwa perkembangan keterampilan praktik IPA meliputi planning, manipulation of equipment, observation, analysing, dan evaluating.

Berdasarkan beberapa pemapaparan tentang practical skills dapat disimpulkan bahwa practical skills merupakan kemampuan kognitif yang harus dimiliki oleh seorang siswa dalam melakukan percobaan, meliputi keterampilan memanipulasi, mengobservasi, menggambar, dan melaporkan serta menginterpretasi.

Berdasarkan permasalahan dan kajian pustaka atau penelitian yang relevan maka pengembangan performance assessment pada guided-PjBL memiliki tujuan yaitu: (1) mengetahui karakteristik performance assessment yang valid dan reliabel untuk mengukur prcatical skills IPA pada guided-PjBL, (2) mendeskripsikan practical skills IPA yang muncul pada guided-PjBL, dan (3) mengetahui pemetaan practical skills IPA siswaSMP menggunakan performance assessment.

\section{METODE}

\section{Jenis Penelitian}

Jenis penelitian ini menggunakan metode research and development (R\&D). Research and development adalah metode penelitian yang digunakan untuk mengembangkan atau memvalidasi produk (Sugiyono, 2014, p.297). Produk pengembangan yang dimaksud dalam penelitian ini adalah lembar observasi performance assessment untuk mengukur practical skills IPA siswa pada guided-PjBL di SMP pada topik "Pencemaran dan Penanggulangannya".

\section{Waktu dan Tempat Penelitian}

Uji coba terbatas dilaksanakan di SMP Negeri 1 Wonosari dan SMP Negeri 4 Playen dari tanggal 9-15 Mei 2015. Uji coba lapangan dilaksanakan di SMP Negeri 1 Wonosari, SMP Negeri 4 Playen, dan SMP Negeri 5 Ngawen dari tanggal 19 Mei-25 Mei 2015.

\section{Target/Subjek Penelitian}

Subjek uji coba produk performance assessment adalah siswa SMP kelas VII semester genap tahun pelajaran 2014/2015. Subjek coba dipilih secara random berdasarkan nilai UNAS IPA tahun 2013 dan dibagi menjadi dua yaitu subjek uji coba terbatas dan uji coba lapangan. Subjek uji coba terbatas menggunakan kelas VII SMP Negeri 1 Wonosari dan SMP Negeri 4 Playen yang berjumlah 100 siswa dan 28 siswa. Subjek uji coba lapangan menggunakan kelas VII SMP Negeri 1 Wonosari, SMP Negeri 4 Playen, dan SMP Negeri 5 Ngawen yang berjumlah 24, 28, dan 28 siswa.

\section{Prosedur Penelitian}

Pengembangan performance assessment dilakukan secara bertahap sesuai dengan langkah R\&D yang diadopsi dari model pengembangan Thiagarajan, et al. (1974). Prosedur pengembangan performance assessment meliputi (1) define (pendefinisian), (2) design (perencanaan), (3) develop (pengembangan), dan (4) disseminate (penyebarluasan). Tahapan pengembangan dijelaskan secara rinci sebagai berikut.

Pertama, pendefinisian. Tahap tersebut memiliki empat komponen utama, yaitu analisis ujung depan, analisis siswa, analisis tugas, dan analisis tujuan pembelajaran. Tahap pendefinisian pada penelitian ini meliputi analisis ujung depan dengan melakukan wawancara pada guru IPA SMP di Kabupaten Gunungkidul terkait masalah cara melakukan penilaian. Analisis siswa yaitu mengetahui karakteristik siswa. Analisis tugas yaitu menentukan materi pembelajaran berdasarkan Kompetensi Inti (KI) dan Kompetensi Dasar (KD) IPA SMP kelas VII. Analisis tujuan pembelajaran yang memuat audience, behaviour, condition, dan degree yang diorganisasikan setiap pertemuan. 
Kedua, perencanaan. Tahap tersebut memiliki enam komponen utama, yaitu menetapkan variabel yang akan diteliti, merumuskan definisi konseptual, menyusun definisi operasional, menyusun kisi-kisi instrumen, menyusun butir instrumen, dan memilih model pembelajaran. Perencanaan dilakukan setelah hasil studi pendahuluan diperoleh.

Ketiga, pengembangan. Tahap tersebut memiliki tiga komponen utama, yaitu validasi penelaah, uji coba terbatas, dan uji coba lapangan. Produk awal yang disebut sebagai draf I divalidasikan ke ahli materi dan ahli evaluasi, selanjutnya mengalami revisi dan menjadi draf II. Draf II kemudian diuji kelayakannya oleh guru IPA, kemudian mengalami revisi dan menjadi draf III. Draf III selanjutnya diujicobakan secara terbatas pada 100 siswa di SMP Negeri 1 Wonosari dan 28 siswa di SMP Negeri 4 Playen. Setelah dilakukan uji coba, draf III mengalami revisi dan menjadi draf IV, disebut sebagai produk akhir. Produk akhir diimplementasikan pada tiga sekolah dengan grade tinggi, sedang, dan rendah utuk mengetahui tingkat kemampuan practical skills IPA siswa.

Keempat, penyebarluasan. Penyebarluasan produk berupa lembar observasi performance assessment pada guided-PjBL dilakukan dengan memberikan produk pada sekolah yang telah dijadikan uji coba.

\section{Teknik dan Instrumen Pengumpulan Data}

Teknik pengumpulan data adalah caracara yang digunakan secara tepat untuk mengumpulkan data dalam penelitian. Teknik pengumpulan data yang digunakan dalam penelitian ini yaitu wawancara, observasi, dan angket. Instrumen yang digunakan dalam pengumpulan data meliputi: pedoman wawancara, lembar observasi, dan lembar angket.

Wawancara pada penelitian ini digunakan sebagai teknik pengumpulan data ketika analisis ujung depan untuk menemukan permasalahan dan urgensi terhadap produk yang harus dikembangkan.Instrumen yang digunakan berupa pedoman wawancara terkaitpenilaian IPA SMP Kurikulum 2013 di Gunungkidul.

Observasi dalam penelitian ini sebagai teknik pengumpulan data melalui proses pengamatan terhadap komponen/variabel penelitian. Teknik observasi ini digunakan pada uji coba lapangan, yaitu mengobservasi practical skills IPA dan keterlaksanaan pembelajaran guided$\mathrm{PjBL}$. Instrumen yang digunakan berupa lembar observasi.
Angket pada penelitian ini merupakan teknik pengumpulan data dengan cara memberi seperangkat pernyataan tertulis kepada responden untuk mendapatkan informasi. Angket dalam hal ini digunakan untuk memperoleh data pada saat validasi produk hasil pengembangan. Instrumen yang digunakan berupa lembar angket.

\section{Teknik Analisis Data}

Data penelitian kemudian dianalisis dan dideskripsikan supaya mudah dipahami. Validitas isi lembar observasi performance assessment dianalisis dengan Aiken's V (Azwar, 2015, p.113).

$$
\begin{array}{ll}
\mathrm{V} & =\sum \mathrm{s} /[\mathrm{n}(\mathrm{c}-1)] \\
\text { Keterangan: } & \\
\mathrm{s} & =\mathrm{r}-\mathrm{lo} \\
\mathrm{lo} & =\text { angka penilaian validitas terendah } \\
\mathrm{c} & =\text { angka penilaian validitas tertinggi } \\
\mathrm{r} & =\text { angka yang diberikan tiap rater }
\end{array}
$$

Validitas internal instrumen dianalisis dengan korelasi product moment (Widoyoko, 2014, p.147).

$$
r_{x y}=\frac{\mathrm{N} \sum \mathrm{XY}-\left(\sum \mathrm{X}\right)\left(\sum \mathrm{Y}\right)}{\sqrt{\left\{\mathrm{N} \sum \mathrm{X}^{2}-\left(\sum \mathrm{X}\right)^{2}\right\}\left\{\mathrm{N} \sum \mathrm{Y}^{2}-\left(\sum \mathrm{Y}\right)^{2}\right\}}}
$$

Keterangan:

$\mathrm{X}=$ skor butir

$\mathrm{Y}=$ skor total

Reliabilitas instrumen dianalisis dengan $\alpha$ Cronbach (Widoyoko, 2014, p.165).Reliabilitas konsistensi antar rater dianalisis dengan formula Ebel (Azwar, 2015, p.89).

$$
\begin{array}{ll}
\overline{\mathrm{r}}_{\mathrm{xx}} & =\left(\mathrm{s}_{\mathrm{s}}{ }^{2}-\mathrm{s}_{\mathrm{e}}{ }^{2}\right) /\left[\mathrm{s}_{\mathrm{s}}{ }^{2}+(\mathrm{k}-1) \mathrm{s}_{\mathrm{e}}{ }^{2}\right] \\
\mathrm{r}_{\mathrm{xx}} & =\left(\mathrm{s}_{\mathrm{s}}{ }^{2}-\mathrm{s}_{\mathrm{e}}{ }^{2}\right) / \mathrm{s}_{\mathrm{s}}{ }^{2}
\end{array}
$$

keterangan:

$\mathrm{s}_{\mathrm{s}}^{2}=$ varians antar-subjek yang dikenai rating

$\mathrm{s}_{\mathrm{e}}{ }^{2}=$ varians eror, yaitu varians interaksi antara subjek (s) dan rater (r)

$\mathrm{k}=$ banyaknya rater yang memberikan rating

Pengukuran practical skills IPA dianalisis dengan konversi skor skala 4 (Mardapi, 2008, p.123).

\section{HASIL DAN PEMBAHASAN}

Hasil penelitian ini berupa lembar observasi performance assessmentpada guided-PjBL. Format lembar observasi performance assessment meliputi: (a) judul, (b) petunjuk pengisian, (3) petunjuk penskoran, (4) peta kompetensi, dan (5) lembar observasi. 
Practical skills yang muncul pada guided$\mathrm{PjBL}$ di materi pencemaran dan penanggulangannya meliputi: (a) merancang proyek, (2) menggunakan termometer dan indikator universal, (3) membaca hasil pengukuran suhu dan $\mathrm{pH}$, (4) membuat tabel, (5) menentukan variabel independent dan variabel dependent pada grafik, (6) membuat grafik, (7) membuat hubungan antar variabel, dan (8) membuat kesimpulan.

Performance assessment pada guidedPjBL yang telah dikembangkan divalidasikan kepada 2 orang dosen ahli. Selain itu juga diuji kelayakannya oleh 3 orang guru IPA. Data hasil validasi dan kelayakan dianalisis menggunakan Aiken's V. Hasil perhitungan validitas isi dapat dilihat pada Tabel 1.

Tabel 1. Hasil Validitas Isi

\begin{tabular}{cc}
\hline No. Butir & Nilai Aiken's V \\
\hline 1 & 1,00 \\
2 & 0,93 \\
3 & 0,93 \\
4 & 1,00 \\
5 & 1,00 \\
6 & 1,00 \\
7 & 0,93 \\
8 & 1,00 \\
9 & 0,87 \\
10 & 0,87 \\
\hline
\end{tabular}

Aiken (1985, p.134) menyatakan bahwa ketika jumlah rater sebanyak 5 orang dan jumlah kategori rating sebanyak 4, butir instrumen dinyatakan valid jika koefisien Aiken sebesar 0,87 . Berdasarkan hasil perhitungan yang tersaji pada Tabel 1, nilai perhitungan Aiken pada masing-masing butir $\geq 0,87$, maka seluruh butir instrumen dinyatakan valid.

Validitas konstruk instrumen dilakukan dengan melakukan expert judgement kepada dosen ahli. Dosen ahli diminta untuk memberi penilaian terhadap masing-masing butir dengan keputusan Layak Digunankan (LD), Layak Digunakan dengan Revisi (LDR), atau Tidak Layak Digunakan (TLD). Setelah dilakukan validasi kontruk, seluruh butir instrumen dinyatakan LD.

Penentuan validitas internal instrumen dilakukan menggunakan instrumen performance assessment pada guided-PjBL untuk menilai practical skills 100 siswakelas VII di SMPN 1 Wonosari. Data yang diperoleh dari hasil uji coba dianalisis dengan dengan rumus korelasi product moment. Hasil perhitungan korelasi product momentdapat dilihat pada Tabel 2.
Tabel 2. Hasil Perhitungan Korelasi Product Moment

\begin{tabular}{cc}
\hline No. Butir & $\begin{array}{c}\text { Nilai Korelasi } \\
\text { Product Momen }\left(\mathbf{r}_{\mathbf{x y}} \text { hitung) }\right.\end{array}$ \\
\hline $\mathbf{1}$ & 0,778 \\
$\mathbf{2}$ & 0,799 \\
$\mathbf{3}$ & 0,847 \\
$\mathbf{4}$ & 0,738 \\
$\mathbf{5}$ & 0,846 \\
$\mathbf{6}$ & 0,611 \\
$\mathbf{7}$ & 0,499 \\
$\mathbf{8}$ & 0,448 \\
$\mathbf{9}$ & 0,494 \\
$\mathbf{1 0}$ & 0,519 \\
\hline
\end{tabular}

Butir instrumen dinyatakan valid jika nilai $r_{x y}$ hitung $\geq r_{x y}$ tabel. Nilai $r_{x y}$ tabel untuk jumlah responden $(\mathrm{N})$ sebanyak 100 siswa adalah 0,195. Berdasarkan hasil perhitungan yang tersaji pada Tabel 2, setiap butir instrumen memiliki nilai $r_{x y}$ hitung $\geq 0,195$, sehingga dapat disimpulkan bahwa semua butir instrumen dinyatakan valid.

Penentuan reliabilitas internal instrumen dilakukan menggunakan instrumen performance assessment pada guided-PjBL untuk menilai practical skills 100 siswa kelas VII di SMP Negeri 1 Wonosari. Data yang diperoleh dari hasil uji coba dianalisis dengan $\alpha$ Cronbach. Setelah dilakukan analisis, nilai alpha sebesar 0,849 . Hal tersebut berarti indeks nilai alpha lebih besar dari standar minimal yaitu $\geq 0,7$ (Widoyoko, 2014, p.149). Artinya instrumen performance assessment pada guided-PjBL yang dikembangkan adalah reliabel.

Penentuan reliabilitas konsistensi antar rater dilakukan oleh tiga rater dengan menggunakan instrumen lembar observasi performance assessment pada guided-PjBL untuk menilai practical skills 28 siswakelas VII di SMP N 4 Playen. Data yang diperoleh dari hasil uji coba dianalisis dengan formula Ebel. Hasil analisis data dapat dilihat pada Tabel 3 .

Tabel 3. Hasil Analisis Reliabilitas Antar Rater

\begin{tabular}{ccc}
\hline No. Butir & $\mathbf{r}_{\mathbf{x x}}$, & $\overline{\mathbf{r}}_{\mathbf{x x}}$ \\
\hline 1. & 0,881 & 0,711 \\
2. & 0,877 & 0,704 \\
3. & 0,943 & 0,847 \\
4. & 0,941 & 0,841 \\
5. & 0,979 & 0,940 \\
6. & 0,978 & 0,937 \\
7. & 0,970 & 0,914 \\
8. & 0,965 & 0,903 \\
9. & 0,981 & 0,944 \\
10. & 0,974 & 0,925 \\
\hline
\end{tabular}


Fraenkel \& Wallen (Susila, 2012, p.10) menyatakan bahwa standar koefisien reliabilitas antar penilai sebesar 0,700. Berdasarkan hasil perhitungan pada Tabel 3, koefisien reliabilitas antar $\operatorname{rater}\left(\mathrm{r}_{\mathrm{xx}}\right)$ lebih dari 0,700 . Hal tersebut berarti pemberian rating yang telah dilakukan oleh ketiga orang rater adalah konsisten antara satu dengan yang lain. Selain itu, hasil koefisien reliabilitas seorang rater $\left(\overline{\mathrm{r}}_{\mathrm{xx}}\right)$ tergolong tinggi. Hal tersebut berarti pemberian rating yang dilakukan setiap rater adalah konsisten.

Setelah lembar observasi performance assessment pada guided-PjBL dinyatakan valid dan reliabel, instrumen tersebut selanjutnya digunakan untuk mengukur tingkat kemampuan practical skills IPA siswa pada guided-PjBL.

Performance assessment pada guided$\mathrm{PjBL}$ digunakan untuk menilai kinerja siswa pada materi pencemaran dan penanggulannya. Alokasi waktu yang digunakan untuk mempelajari materi tersebut adalah 8 jam pelajaran ( 8 JP) dengan menggunakan tiga kali pertemuan. Pertemuan ke-I siswa mempelajari tentang pengaruh lingkungan terhadap kecepatan bernapas makhluk hidup yang ada di air, pertemuan ke-II siswa mempelajari tentang pencemaran air dan filtrasi, dan pertemuan ke-III siswa mempelajari tentang gejala efek rumah kaca. Keterlaksanaan guided-PjBL selama tiga kali pertemuan dapat dilihat pada Gambar 1.

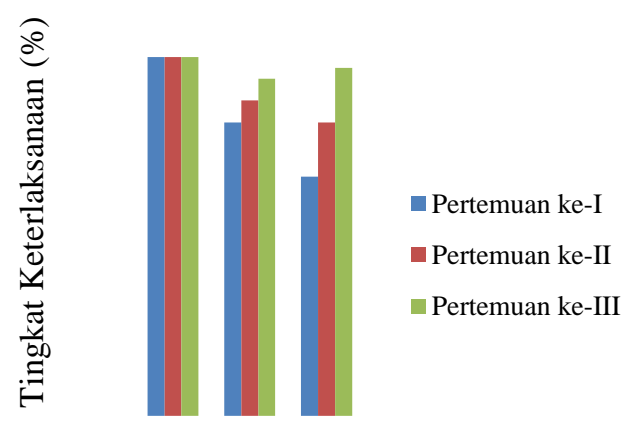

Kategori Sekolah

\section{Gambar 1. Grafik Keterlaksanaan Guided-PjBL}

Tingkat keterlaksanaan guided-PjBL pada sekolah kategori sedang dan rendah mengalami peningkatan dari pertemuan ke-I sampai pertemuan ke-III. Hal tersebut jika dihubungkan dengan tingkat kemampuan practical skills IPA, guided-PjBL dapat meningkatkan performance siswa sehingga kemampuan practical skills IPA juga "meningkat". Makna dari "meningkat" di sini adalah siswa yang pada pertemuan ke-I memiliki penguasaan practical skills yang kurang, dengan adanya model guided-PjBL, penguasaan practical skills pada indikator yang sama jauh lebih mahir.

Practical skills IPA yang diukur meliputi: (a) merancang proyek, (b) menggunakan termometer, (3) menggunakan indikator universal, (4) membaca hasil pengukuran suhu, (5) membaca hasil pengukuran $\mathrm{pH}$, (6) membuat tabel, (7) menentukan variabel independent dan dependent pada grafik, (8) membuat grafik, (9) membuat hubungan antar variabel, dan (10) membuat kesimpulan.

Pertama, siswa mampu merancang proyek berdasarkan alat dan bahan yang telah disediakan oleh guru. Tingkat kemampuan siswa pada tiga kategori sekolah tersaji pada Gambar 2.

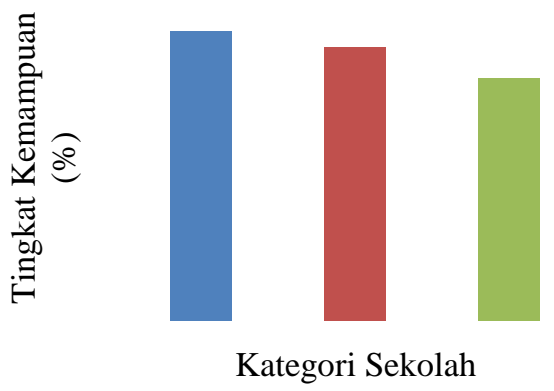

Gambar 2. Grafik Rata-rata Kemampuan Siswa Merancang Proyek pada Proyek Ke-I, II, dan III

Berdasarkan Gambar 2, dapat dilihat bahwa siswa pada sekolah kategori tinggi memiliki kemampuan merancang proyek paling tinggi sedangkan siswa pada kategori rendah memiliki kemampuan merancang proyek paling rendah.

Kedua, siswa mampu menggunakan termometer. Tingkat kemampuan siswa pada tiga kategori sekolah tersaji pada Gambar 3.

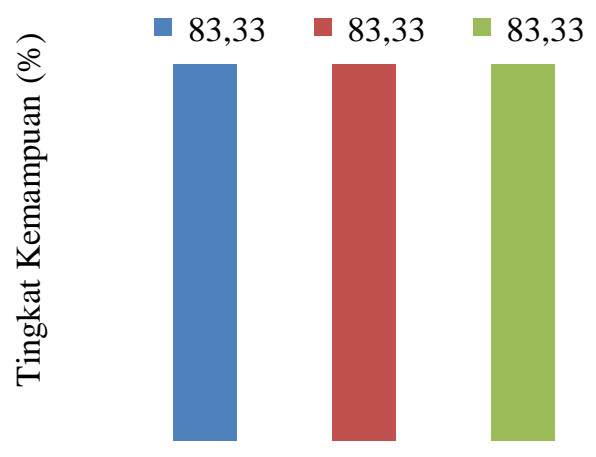

Kategori Sekolah

Gambar 3. Grafik Rata-rata Kemampuan Siswa Menggunakan Termometer 
Berdasarkan Gambar 3, dapat dilihat bahwa siswa pada sekolah kategori tinggi, sedang, dan rendah memiliki tingkat kemampuan yang sama dalam menggunakan termometer.

Ketiga, siswa mampu menggunakan indikator universal. Tingkat kemampuan siswa pada tiga kategori sekolah tersaji pada Gambar 4.

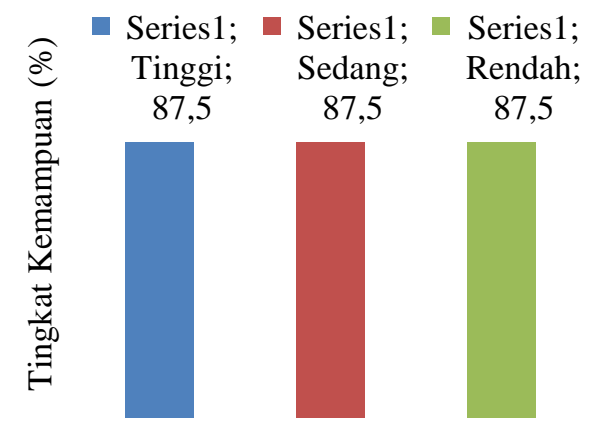

Kategori Sekolah

Gambar 4. Grafik Rata-rata Kemampuan Peserta Didik Menggunakan Indikator Universal

Berdasarkan Gambar 4, dapat dilihat bahwa siswa pada sekolah kategori tinggi, sedang, dan rendah memiliki tingkat kemampuan yang sama dalam menggunakan indikator universal.

Keempat, siswa mampu membaca hasil pengukuran suhu. Tingkat kemampuan siswa pada tiga kategori sekolah tersaji pada Gambar 5.

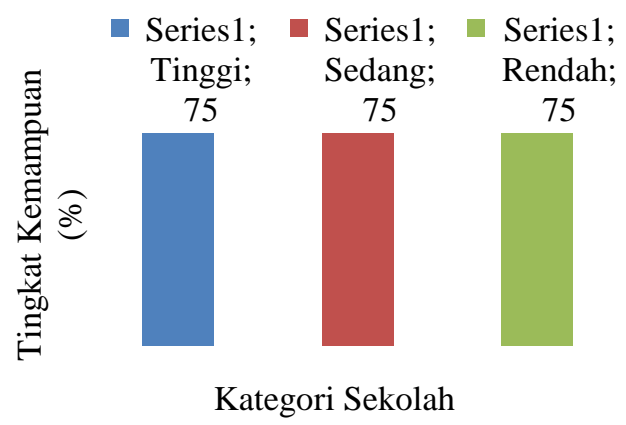

Gambar 5. Grafik Rata-rata Kemampuan Peserta didik Membaca Hasil Pengukuran Suhu

Berdasarkan Gambar 5, dapat dilihat bahwa siswa pada sekolah kategori tinggi, sedang, dan rendah memiliki tingkat kemampuan yang sama dalam membaca hasil pengukuran suhu.

Kelima, siswa mampu membaca hasil pengukuran $\mathrm{pH}$. Tingkat kemampuan siswa pada tiga kategori sekolah tersaji pada Gambar 6.

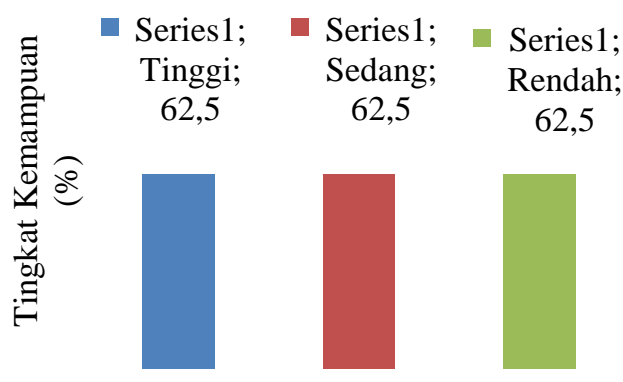

Kategori Sekolah

Gambar 6. Grafik Rata-rata Kemampuan Peserta Didik Membaca Hasil Pengukuran $\mathrm{pH}$

Berdasarkan Gambar 6, dapat dilihat bahwa siswa pada sekolah kategori tinggi, sedang, dan rendah memiliki tingkat kemampuan yang sama dalam membaca hasil pengukuran $\mathrm{pH}$.

Keenam, siswa mampu membuat tabel. Tingkat kemampuan siswa pada tiga kategori sekolah tersaji pada Gambar 7.

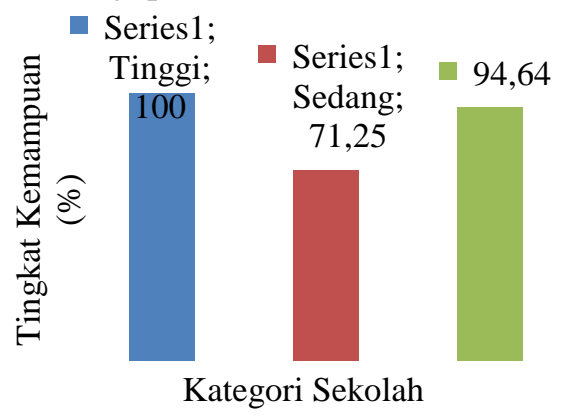

Gambar 7. Grafik Rata-rata Kemampuan Peserta Didik Membuat Tabel

Berdasarkan Gambar 7, dapat dilihat bahwa siswa pada sekolah kategori tinggi memiliki kemampuan membuat paling tinggi sedangkan siswa pada kategori sedang memiliki kemampuan membuat tabel paling rendah.

Ketujuh, siswa mampu menentukan variabel independent dan dependent pada grafik. Tingkat kemampuan siswa pada tiga kategori sekolah tersaji pada Gambar 8.

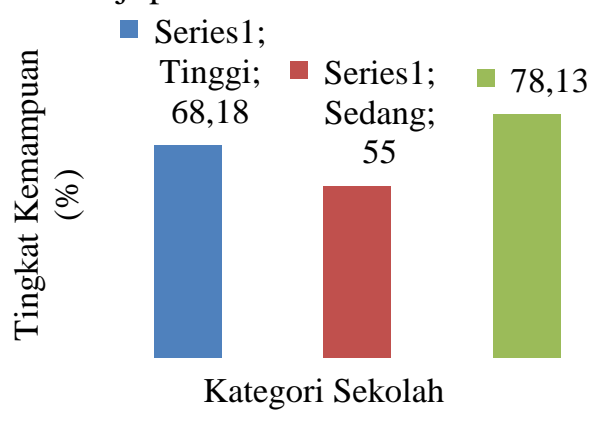

Gambar 8. Grafik Rata-rata Kemampuan Siswa Menentukan Variabel Independent dan Dependent pada Grafik 
Berdasarkan Gambar 8, dapat dilihat bahwa siswa pada sekolah kategori rendah memiliki kemampuan menentukan variabel independent dan dependent pada grafik paling tinggi sedangkan siswa pada kategori sedang memiliki kemampuan menentukan variabel independent dan dependent pada grafik paling rendah.

Kedelapan, siswa mampu membuat grafik. Tingkat kemampuan siswa pada tiga kategori sekolah tersaji pada Gambar 9.

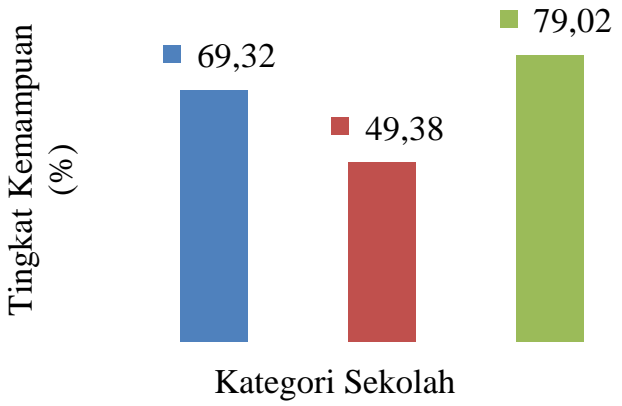

Gambar 9. Grafik Rata-rata Kemampuan Siswa dalam Membuat Grafik

Berdasarkan Gambar 9, dapat dilihat bahwa siswa pada sekolah kategori rendah memiliki kemampuan membuat grafik paling tinggi sedangkan siswa pada kategori sedang memiliki kemampuan membuat grafik paling rendah.

Kesembilan, siswa mampu membuat hubungan antar-variabel. Tingkat kemampuan siswa pada tiga kategori sekolah tersaji pada Gambar 10.

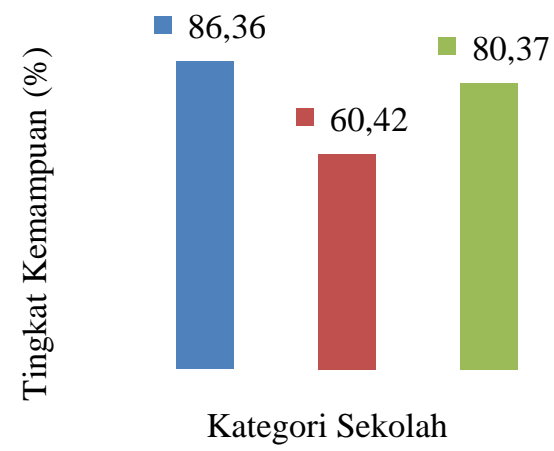

Gambar 10. Grafik Rata-rata Kemampuan Siswa Membuat Hubungan Antar Variabel

Berdasarkan Gambar 10, dapat dilihat bahwa siswa pada sekolah kategori rendah memiliki kemampuan membuat hubungan antar variabel paling tinggi sedangkan siswa pada kategori sedang memiliki kemampuan membuat hubungan antar variabel paling rendah.

Kesepuluh, siswa mampu membuat kesimpulan. Tingkat kemampuan siswa pada tiga kategori sekolah tersaji pada Gambar 11.

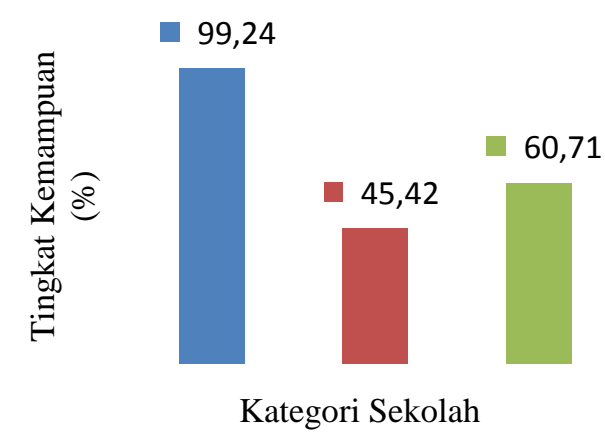

Gambar 11. Grafik Rata-rata Kemampuan Siswa Membuat Kesimpulan

Berdasarkan Gambar 11, dapat dilihat bahwa siswa pada sekolah kategori tinggi memiliki kemampuan membuat kesimpulan paling tinggi sedangkan siswa pada kategori sedang memiliki kemampuan membuat kesimpulan paling rendah.

Setelah dilakukan pengukuran practical skills IPA siswa pada sekolah kategori tinggi, sedang dan rendah, ternyata tingkat kemampuan siswa berbeda-beda yang dapat dilihat pada Gambar 12.

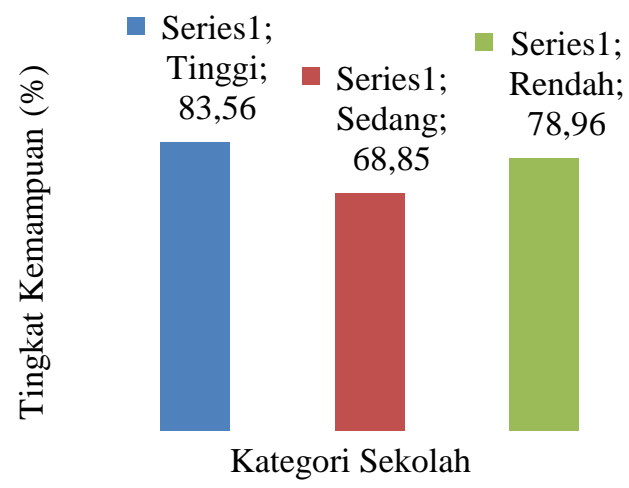

\section{Gambar 12. Grafik Rata-rata Prcatical Skills di Berbagai Kategori Sekolah}

Berdasarkan Gambar 12 dapat dilihat bahwa siswa pada sekolah kategori tinggi memiliki tingkat kemampuan practical skills paling tinggi dibandingkan siswa pada sekolah kategori sedang maupun rendah. Siswa pada sekolah kategori sedang memiliki tingkat kemampuan practical skills paling rendah dibandingkan siswa pada sekolah kategori tinggi maupun rendah. Siswa pada sekolah kategori rendah memiliki tingkat kemampuan practical skills lebih tinggi dibandingkan siswa pada sekolah kategori tinggi namun lebih rendah dibandingkan siswa pada sekolah kategori tinggi. 


\section{SIMPULAN DAN SARAN}

\section{Simpulan}

Berdasarkan pengembangan produk yang telah dilakukan dapat disimpulkan bahwa lembar observasi performance assessment untuk mengukur kompetensi practical skills IPA pada guided-PjBL dinyatakan valid dan reliabel. Practical skill yang muncul pada guided-PjBL meliputi: (a) merancang proyek, (b) menggunakan termometer dan indikator universal, (c) membaca hasil pengukuran suhu, dan $\mathrm{pH}$, (d) membuat tabel, (e) menentukan variabel independent dan dependent pada grafik, (f) membuat grafik, (g) membuat hubungan antar-variabel, dan (h) membuat kesimpulan. Siswa yang sekolah di kategori tinggi memiliki tingkat practical skills paling tinggi bila dibandingkan dengan siswa yang sekolah di kategori sedang maupun rendah.Siswa yang sekolah di kategori sedang memiliki tingkat practical skills paling rendah bila dibandingkan dengan siswa yang sekolah di kategori tinggi maupun rendah. Siswa yang sekolah di kategori rendah memiliki tingkat practical skills lebih tinggi bila dibandingkan dengan siswa yang sekolah di kategori sedang, namun lebih rendah bila dibandingkan dengan siswa yang sekolah di kategori tinggi.

\section{Saran}

Berdasarkan penelitian dan pengembangan performance assessment pada guided-PjBL, guru dapat mengembangkan performance as sessment pada materi yang lain dan model pembelajaran yang lain. Selain itu, guru jangan hanya menitikberatkan kepada kompetensi pengetahuan, namun juga kompetensi keterampilan. Hal tersebut dikarenakan siswa yang cukup menguasai kompetensi pengetahuan belum tentu juga menguasai kompetensi keterampilan dengan baik juga.

\section{DAFTAR PUSTAKA}

Aiken, L. R. (1985). Three coefficients for analyzing the reliability and validity of rating. Educational and Psychological Measurement, 45, 131-142.

Azwar, S. (2015). Reliabilitas dan validitas (4 ed.). Yogyakarta: Pustaka Pelajar.

Baker, E., Breanna, T., Otto, P., Tudor, M., \& Ferguson, L. (2011). Project-basedlearning model, relevant learning for the 21th century. Washington D.C: Pacific Education Institute.
Bagheri, M., Ali, W. Z., Chong, M., \& Daud, S. M. (2013). Effect of project-based learning strategy on self-directed learning skills of educational technology students. Contemporary Educational Technology, 4, 15-29.

Bender, W. N. (2012). Project based learning, differentiating instruction for the 21st century.Kalifornia: Corwin.

Central Board of Secondary Education. (2009). Assessment of practical skills in Science. Delhi: Central Board of Secondary Education.

Craw, K. G. (2009). Performance assessment practices: a case study of science teacher in a suburban high school setting. Disertasi doktor, Columbia University.

Republik Indonesia. (2003). Undang-undang RI nomor 20 tahun 2003, tentang sistem guruan nasional.

Presiden. (2005). Peraturan pemerintah RI nomor 19 tahun 2005, tentang standar nasional guruan.

Guo, S., \& Yang, Y. (2012). project-basedlearning: an effective approach to link teacher professional development and student learning. Journal Educational Technology Development and Exchange, 5, 41-56.

Hampton, C. (2002). Teaching practical skills. Canada: Commonwealth of Learning.

Hosnan, M. (2014). Pendekatan saintifik dan kontekstual dalam pembelajaran abad 21. Bogor: Ghalia Indonesia.

Keser, H., \& Karahoca, D. (2010). Designing a project management e-course by using project based learning. Sciense Direct, 2, 5744-5754.

Kunandar. (2014). Penilaian autentik (penilaian hasil belajar peserta didik berdasarkan kurikulum 2013). Jakarta: Raja Grafindo Persada.

Lock, R. (1989). Assessment of practical skills part 1. the relationships between component skills. Research in Science \& Technological Education, 7 (2), 221233.

Doi: http://www.tandfonline.com/doi/abs/10. 1080/0263514890070209 
Mardapi, D. (2008). Teknik penyusunan instrumen tes dan nontes. Yogyakarta: Mitra Cendikia Press.

Mcgrath, D. (2002). Getting started with project based learning. Learning \& Leading with Technology, 30, 130-136.

Mihardi, S. (2013). The effect of project based learning model with kwl worksheet on student creative thinking process in physics problems. Journal of Education and Practice, 4.

Miller, M. D., Linn, R. L., \& Groundlund, N. E. (2009). Measurement and assessment in teaching. Ohao: Merrill Publishing Company.

Paige, R. M. (2005). Internatioalization of higher education: performance assessment and indicator. University of Minnesota, College of Education and Human Development.

Patton, A. (2012). Work that Matter: The teacher's guide to project-basedlearning. London: Paul Hamlyn Foundation.

Pickens, B. C., Lancaster, C., Scaefgen, B., James, R. K., \& Constantine, D. (2012). Project based learning: enriching counselor education through real world learning. Article VISTAS, 1, 1-12.

Sugiyono. (2014). Metode penelitian kuantitatif kualitatif dan $R \quad \& \quad D$. Bandung: Alfabeta.

Susila, I. K. (2012). Pengembangan instrumen penilaian unjuk kerja (performance assessment) laboraturium pada mata pelajaran fisika sesuai Kurikulum Tingkat Satuan Guruan SMA kelas X di Kabupaten Gianyar. Artikel . Diambil pada tanggal 17 Oktober 2014 dari http://pasca.undiksa.ac.id/ejournal/index.php/jurnal_ep/article/dow nload/375/167

The George Lucas Educational Foundation. (2005). Instructional module project based learning. Diambil pada tanggal 16 Oktober 2014 dari
http://www.edutopia.org/modules/PBL/ whatpbl.php

Thiagarajan, S., Semmel, D. S., \& Semmel, M. I. (1974). instructional development for training teachers of exceptional children. leadership trining institutel special education: minneapolis. Minnesota: University Of Minneasota.

van Helvoort, J. (2010). A scoring rubric for performance assessment of information literacy in Dutch higher education. Journal of Information Literacy, 4, 2239.

Watts, A. (2013). The assessment of practical science: a literature review. Cambridge Assessment .

Widoyoko, E. P. (2014). Teknik penyusunan instrumen penelitian. Yogyakarta: Pustaka Pelajar.

Wisconsin Education Association Council. (1996). Performance assessment. Education Issues Series.

Wolf, K., \& Stevens, E. (2007). The role of rubrics in advancing and assessing student learning. The Journal of Effective Teaching, 7, 3-14.

Wood, R., Ferguson, \& Carolyn, M. (1975). Teacher assessment of practical skills in a-level chemistry. School Science Review, 56, 605-608.

Woodley, E. (2009). Practical work in school science-why is it important? Article School Science Review, 91, 49-51.

Wren, D. G. (2009). Performance assessment: a key component of a balanced assessment system. Report from the Departement of Research, Evaluation, and Assessment, 2, 1-12.

Zainul, A. (2001). Alternative assessment. Jakarta: PAU-PPAI, Universitas Terbuka.

Zitzewitz. (2004). Alternative assessment in the science classroom. New York: McGraw-Hill. 